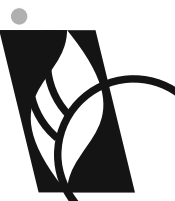

J O U R N A L

$\mathrm{O} F \bullet \mathrm{B} \mathrm{A} \mathrm{L} \mathrm{T} \mathrm{I} \mathrm{C}$

$S$ C I E N C E

E DUCATION

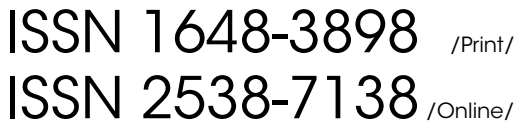

Abstract. In a teaching and learning process, the mastery of mathematics would support students in learning physics.

The aim of the research is to analyse the difficulties of physics teachers' in conduct-

ing teaching and learning process that demands the requirements of mathemati-

cal concepts in senior high schools. The research was a qualitative research using

phenomenological approach. The data were collected through focus group discussion (FGD) that involved 15 teachers from public and private senior high schools in the Kudus Regency, the Province of Central

Java, Indonesia. The analysis was conducted by applying the Bogdan \& Biklen model. The results of the research showed several findings if there had been problems of un-synchronism in the material orders of mathematics and physics that hindered

the teaching and learning process. The strategies that physics teachers had applied

individually are teaching mathematics materials as prerequisite first and making module collaboratively. The new arrangement of teaching and learning materials in mathematics and physics are needed to cover the problems.

Keywords: mathematics mastery, physics teaching, learning process, difficulties and strategies

Heri Retnawati

Yogyakarta State University, Indonesia Janu Arlinwibowo Muhammadiyah Health Sciences School of Kudus, Indonesia

Nidya F. Wulandari

Yogyakarta State University, Indonesia

Rian G. Pradani

SMAN 1 Gebog Kudus, Indonesia

\section{TEACHERS' DIFFICULTIES AND STRATEGIES IN PHYSICS TEACHING AND LEARNING THAT APPLYING MATHEMATICS}

\author{
Heri Retnawati, \\ Janu Arlinwibowo, \\ Nidya F. Wulandari, \\ Rian G. Pradani
}

\section{Introduction}

One question that usually comes to the surface is how to solve a problem without a tool. Another question might be how to solve physics problems without using mathematics requirements. Based on the existing research, mathematics has ever expanded impact toward the other disciplines ( $\mathrm{Na}$ tional Research Council, 2013). The expansion has been taking place for several decades; however, the expansion has rapidly grown within the last 10-120 years. As the implication, mathematics has been applied to various fields and various efforts in solving multiple cases or incidents. The important characteristic of mathematics is that mathematics encompasses other fields (Redish \& Bing, 2009; Simons, 2001; Steiner, 1998). This characteristic does not simply mean that mathematical concepts and calculations are applied into the other fields; instead, this characteristic has a more complex meaning.

In addition, much of the nowadays science and technology has been built upon the calculation and the simulation in mathematics. Technology has always been expanding and, as a consequence, human resources should be competent in operating the technology (Chiu, 2015; Pietrocola, 2008; Quale, 2011; Redish, 2006). Wigner (2060) asserted that mathematics has played an important role in physics. Physics and mathematics are interrelated (Pospiech et al., 2009). Then, he also explained that in the fundamental level mathematics explains the abstract forms and models, while physics tends to explain more about natural phenomena using mathematics concept and connection. In addition, Steiner (1977) stated that true physics follows mathematics notation. However, Redish, and Bing (2009) explained that the mathematics symbols should be reinterpreted in order to follow the general requirements of physics.

The important role of mathematics will be understood more by students as they enter higher educational degree. Mathematics is a problem-solving tool in physics; specifically, mathematics can predict the system in physics 
(Chiu, 2015; Quale, 2011). However, Uhden, Karam, Pietrocola \& Pospiech (2011) argued that mathematics has been more than a problem-solving tool in physics and that the discussions on several physics materials are essentially mathematics. Mathematics serves as prerequisite teaching and learning material for physics (Pietrocola, 2008; Redish, 2005; Redish \& Bing, 2009) and mathematics also serves as an essential element in the problem-solving efforts for physics (Redish, 2005). Therefore, if an individual wants to study physics then he or she should understand mathematics first. Pospeich (2009) also argued that it has been very important to identify the mathematics proficiency first in modelling a problem that becomes the main objective of physics teaching and learning. Based on these statements, the researchers would like to assert that mathematics has supported the learning process of other lessons and this includes physics, concept mastery of physics, and also physics application and analysis. Looking at this situation, the core of technological competence is physics and nowadays technology has been an inseparable part of human beings' life. Therefore, it is for granted that physics teaching and learning becomes urgency in the domain of education. Unfortunately, in the practice physics has been considered as a difficult subject in the school (Duit, Niedderer \& Schecker, 2007).

Mathematics and physics are knowledge and science that have a close relationship (Gingras, 2001). This relationship is expressed as a two-way process (mathematics is a method used in physics and physics is one of material used in mathematics), the proximity of the study object, the historical closeness, and this closeness affects the teaching and learning of the two subjects (Tzanakis, n.d.). Mathematics is used to solve problems in physics from elementary to high school and a tool for developing theory in physics (Doran, 2017). Mathematics has many branches, namely algebra, geometry, analysis, probability and statistics. For example, geometry is one of the branches in mathematics, which contributes to the development of modern physics (Atiyah, n.d.). The close relationship between mathematics and its branches with physics impacts on teaching and learning in physics.

Ideally, physics education is conducted based on the standards of the science education standards. This standard states that the learning process of science is planned and implemented in inquiry-based learning (National Research Council, 1996). When conducting this inquiry teaching and learning, there are several steps that students do. American Association of Physics Teachers (2015) stated that these steps are "asking questions, developing and using models, planning and carrying out investigations, analyzing and interpreting data, using mathematics and computational thinking, constructing explanations, engaging in argument from evidence, evaluating and communicating information". In almost all of these physics learning steps, mathematics including its branches provides an important role. Math is necessary to complete these steps. The process is to construct concepts that include patterns, causality, scale, energy and matter, structure and function, and stability and change (American Association of Physics Teachers, 2015). The concept constructed in the science study, for physics in particular, is expressed as a mathematical relationship.

Students' difficulties in teaching and learning physics are related to their mathematical ability that has not been sufficient for associating the mathematical concepts to physics knowledge (Pospeich et al., 2009). Principally, Tasar (2010) explained that learning activities should be started from concrete matters to abstract matters, from the known to the unknown, from the near to the far, from the easy to the complex. He also added that, for example, students should learn the matters that they have already known in order to learn the matters that they have not known. This statement implies that mathematical concept as the basis of physics should be taught first. If the mathematical concept has not been taught, while in the same the curriculum of physics demands that physics should be taught immediately, then students will have difficulties in attending physics teaching and learning process which demands mathematical requirements. A study by Lawrenz, Wood, Kirchhoff, Kim, \& Eisenkraft (2009) found that mathematical abilities impact students' understanding toward physics. Students in all educational degrees and in all ages have difficulties in teaching and learning physics not solely due to the complexity of the lesson; instead, they also suffer from those difficulties because of their knowledge and proficiency in understanding mathematics as the prerequisite in learning physics have not been sufficient (Basson, 2002; Linn, Tan, \& Tsai, 2013; Pietrocola, 2008). Mathematics materials that will be applied as the basis in physics should be taught in the lower degrees before students learn about physics. For instance, students learn about location, coordinate, angle, and time in the lower degree prior to teaching and learning the concept of velocity and acceleration.

The importance of mathematics in this case can be seen from the fact that students who have mathematical abilities do not have any guarantee of success in teaching and learning physics; in other words, students who do not have sufficient mathematical ability, will certainly have weak physical ability (Chiu, 2015; Hudson \& Mclntire, 1977; Pietrocola, 2008). Without knowledge of mathematics, it is impossible to attain good knowledge of physics. However, in the reality the phenomenon is that physics teachers spend a great deal of time to teach students 
about mathematics earlier and quicker since they have not mastered mathematics well, whereas mathematics is a prerequisite in teaching and learning physics (Basson, 2002). The complaint that physics teachers convey most of the time is that the students have not been able to apply the knowledge that they attain in the mathematics class into the physics class (Basson, 2002). In addition, mathematics is often considered as the cause of students' failure in teaching and learning physics; students have not understood physics well because they have weakness in their concept of mathematics (Pietrocola, 2008). Therefore, several experts consider that the fundamental ability in mathematics provides greater opportunity to achieve success in teaching and learning physics. This situation then will be the one that has forced physics teachers to teach mathematics first.

Mathematics has been taught first because it is a necessary tool in teaching and learning physics. As a consequence, physics teachers have greater challenges than do mathematics teachers. In addition, physics curriculum demands physics teachers to teach several contents that have been more challenging (Chiu, 2015). Different than mathematics curriculum, which aims to improve the thinking skills rather than the quality of the content under study, physics curriculum has more emphasis on improving the content under study as a form of rapid scientific development that does not negate the importance of mathematics as a tool in teaching and learning physics (Chiu, 2015). It is this heavier load that becomes the difficulty and the stress on physics teachers' part if mathematics curriculum does not support physics curriculum and if mathematics teachers have not taught the contents that support physics teaching and learning process.

Chiu (2005) underlined six challenges that physics teachers encounter in implementing the physics teaching and learning process prior to teaching the mathematics curriculum to the students, namely: (1) political challenge: the national curriculum emphasizes the higher education policy rather than the high education policy; (2) social challenge: there have been plenty of interventions in education; (3) scientific challenge: the borders between the subjects and the knowledge have increased in schools; (4) teaching and learning challenge: the number of HOTS-based learning process has still been low; (5) justice challenge: there has been inequality in the learning opportunity; and (6) teaching challenge: the burdens of physics teachers have increased because of the urgency to teach mathematics and of the mathematics teachers' confusion in re-teaching the learning materials that have been studied in physics. Therefore, physics teachers should be confirmed first that the implemented curriculum has provided a prerequisite in the form of sufficient mathematical concepts mastery as the basis for studying physics. In addition, physics teacher should pay attention to the curriculum sequence that has been synchronized to the subjects that have been taught along with their prerequisite lessons. In this case, ideally the mathematical prerequisites should be studied first prior to studying physics. If the mathematical competency is necessary for solving the physical problems, then it will be wiser to teach mathematics first (Nahson, Anderson \& Nielsen, 2009).

To be able to apply mathematical abilities in physics teaching and learning, mastery of mathematical concepts becomes the main key. Some obstacles faced by students namely the lack of mastery of concepts in mathematics cause students less able to connect between concepts to solve problems (Retnawati, Kartowagiran, Arlinwibowo, \& Sulistyaningsih, 2017; Sari \& Wijaya, 2017). Teaching and learning that train many abilities, for example train the mathematics ability first and then train physics abilities and skills cause teachers to work too hard, especially teachers also have the task of carrying out the assessment. Teachers' difficulties in carrying out such complex learning require long time (Retnawati, Munadi, Arlinwibowo, Wulandari, Sulistyaningsih, 2017), and cause difficulties in conducting assessment (Retnawati, Nugraha, \& Hadi, 2016). Strategies that can be done are organizing the material of teaching and learning in a learning trajectory (Retnawati, 2017), which considers certain prerequisite materials.

The importance of material distribution sequence and of prerequisite materials distribution has also been based on the results of a study by Tasar (2010), which found that students' difficulties in understanding the concept of velocity in physics have been related to their misconception in mathematical concepts. The simple mathematical concepts may develop into the complex ones when it comes to physics under various phenomena. If the students still have misconceptions in the simple mathematical concepts, then they will suffer from difficulties in solving simple physical problems (Chiu, 2015; Hudson \& McIntire, 1997; Pietrocola, 2008). This is the importance of synchronizing inter-disciplinary curriculum contents that have been interrelated. This statement is supported by the results of a study by Aziz (1988) which found that students who attend the integrated learning process between mathematics and physics have better abilities in combining, implementing, analysing, and synthesizing categories. If the contents are not synchronized, as it is the case in Indonesian curriculum, then there will be many problems that may occur. The teachers in several schools do not mind such problem although it has occurred for several years. 


\section{Research Focus}

In relation to this situation, there should be a research to describe this peculiarity, especially the physics teachers' difficulties and strategies in conducting the learning process that demands the prerequisites in the form of mathematical concepts in senior high schools.

\section{The Researcher's Role}

In this research, the researchers mapped the materials in physics and mathematics, then identify the necessary prerequisite materials in physics that need mathematical concepts. Researchers then describe the difficulties and strategies of physics teachers when implementing physics teaching and learning that requires mathematical prerequisite. In this research activity, the researchers become observers and do not participate in anything related to the implementation of physics teaching and learning conducted by the teacher.

\section{Methodology of Research}

\section{Design}

The research was a qualitative research using phenomenological approach (Creswell \& Clark, n.d.). The research was conducted in order to attain understanding toward the difficulties that the physics teachers in senior high schools encounter in relation to the utilization of mathematical concepts as modelling of physics concepts and analysing data and interpreting after experiments, and in all steps of inquiry based learning. Furthermore, the researchers in the research explored the strategies that the physics teachers implemented in dealing with these problems.

The scope of the research includes mathematics curriculum and physics curriculum for senior high schools and also the physics teachers' difficulties and strategies in conducting the physics teaching and learning process that demanded the mathematical concepts. The curriculum was implemented in mapping the physics competencies that demanded the mathematical prerequisites and their position in the teaching and learning process.

The research was conducted in January-September 2017. In January-March 2017, researchers made the mapping of mathematics curriculum and physics curriculum for senior high schools. The mapping was conducted by 2 mathematics education experts and 1 physics teacher of senior high school. The data regarding the physics teachers' difficulties and strategies in the teaching and learning process that demanded the prerequisites in the form of mathematical concepts in senior high schools were gathered using focus group discussion (FGD).

The FGD was conducted in May 2017. It formed once time, caused researcher prepared the mapping of mathematics curriculum and physics curriculum for senior high schools and many topics about physics teachers' difficulties and strategies in the teaching and learning process. In the forum, all of topics discussed completely and clearly.

\section{Participants}

The FGD participants were 15 physics teachers (post service) for Senior High School in Kudus Regency, the Province of Central Java, Indonesia and one mathematics education expert from a university. These participants consisted of 10 male informants and 5 female informants. The qualification of the teachers who had been invited into the FGD was the mathematics teachers who had been teaching physics in senior high schools with Educational Bachelor degree in physics education study program.

\section{Data Analysis}

The mapping of mathematics and physics in senior high schools was scrutinized by the FGD participants in order to provide their judgment toward the necessity of implementing mathematics into the physics learning process. Afterwards, the researchers identified the physics teachers' difficulties in implementing the physics learning process that made use of mathematics prerequisite materials and the strategies that the physics teachers had implemented up to date. The results of the FGD then were analysed using the qualitative analysis model by Bogdan \& Biklen (1982). The stages of analysis in this research were data reduction, sub-theme identification, inter-theme relationship establishment, and conclusion. 


\section{The Ethical Considerations}

To ensure the data obtained in this research is credible, all participants are encoded. The purposes of the research were presented to the participants clearly. The researchers assured all of participants that the research results do not affect anything to them.

\section{Results of Researches}

\section{Physics Teachers' Difficulties}

Mathematics including its branches, they are algebra, geometry, analysis, probabilities and statistics contribute greatly to the inquiry in physics teaching and learning process. The whole process is the stage for students to construct the concepts in physics. The mathematical urgency to support physics learning is realized by the teacher. The data on the reduction of mathematics role in supporting the physics teaching and learning process in senior high schools are viewed in Table 1.

Table 1. Teachers' perceptions about the mathematics role in supporting the physics teaching and learning process.

\begin{tabular}{|c|c|c|}
\hline Teacher Perceptions & Theme & Inter-Theme Association \\
\hline $\begin{array}{l}\text { 1. Mathematics is a tool for explaining physical phe- } \\
\text { nomena. } \\
\text { 2. Mathematics is a universal language. } \\
\text { 3. Mathematics is the basis of physics. }\end{array}$ & $\begin{array}{l}\text { Multiple mathematics materials } \\
\text { have the role of physics prerequi- } \\
\text { site materials. }\end{array}$ & \multirow{3}{*}{$\begin{array}{l}\text { Nowadays the role of math- } \\
\text { ematics as the fundamental } \\
\text { knowledge in supporting physics } \\
\text { has been moderately low. }\end{array}$} \\
\hline $\begin{array}{l}\text { 1. The teaching and learning materials sequence } \\
\text { between mathematics and physics have not been } \\
\text { synchronized. } \\
\text { 2. There has not been any specific review toward the } \\
\text { sequence appropriateness. }\end{array}$ & $\begin{array}{l}\text { The supporting ability of mathemat- } \\
\text { ics proficiency as a prerequisite in } \\
\text { mathematics has still been low. }\end{array}$ & \\
\hline $\begin{array}{l}\text { 3. The physics teachers scrutinize the learning materials } \\
\text { sequence of mathematics and physics only when they } \\
\text { have found problems. }\end{array}$ & & \\
\hline
\end{tabular}

Physics heavily demands mathematics because this lesson serves as the tool that manipulates information into easily understood conclusion. Various phenomena should be explained through both calculation process and mathematical modelling: Therefore, mathematics becomes a tool in the process of searching the physical phenomena so that mathematics generates physical conclusions. Mathematics is a universal language that describes multiple phenomena so that these phenomena might be easily understood, and this includes physics as well. Mathematics language plays a role in describing multiple natural phenomena such as temperature, frequency, length, speed, velocity, and alike accurately.

The role of mathematics as a tool and a language shows that in order to understand physics one should have enough mathematical proficiency. All teachers agreed that mathematics has been the fundamental science that students should master before they study physics. Many teaching and learning materials in mathematics are the prerequisite in physics, such as trigonometry in mathematics supports the teaching and learning materials of vectors, and geometry supports modelling in physics.

The Indonesian education has undergone several curriculum changes periodically, which has been followed by the changes on the material contents and arrangement. In the last several years, there have been curriculum changes from the Competence Based Curriculum to the School Unit Level Curriculum to the Curriculum 2013. Despite these changes, the teachers do not perceive any positive impact regarding the match of teaching and learning materials order between mathematics and physics. An analysis toward the latest regulation, namely the Minister of Education and Culture Regulation Number 24 Year 2016 regarding the Core Competencies and the Basic Competencies of the Lessons in the Curriculum 2013 has found multiple mismatches on the teaching and 
learning materials order between mathematics and physics and these mismatches are shown by the frequently absent mathematics teaching and learning materials in the teaching and learning process by the time that physics teaching and learning materials should have been taught, especially in the first semester of grade X and grade XI.

The first fact that displays the mismatches on the teaching and learning materials order between mathematics and physics is that the teaching and learning materials for statistics in mathematics are taught in the second semester of Grade XII, whereas the statistical abilities are necessary since grade X. Physics is heavily associated to laboratory practice; in fact, all teaching and learning materials are taught using experiments as an effort of reinforcing the students' theoretical understanding. Statistics is the fundamental science for attaining the physical concepts through the laboratory practice because in the progress the students demand the ability of processing the data such as presenting the data (graphics and tables) along with the processing results (mean, median, and mode) in order to conclude the results of their measurement along with its uncertainty (errors).

Several mathematics teaching and learning materials inhibit the physics teaching and learning process because the competencies in these teaching and learning materials are necessary within the physics learning process, yet these learning materials have not been taught. These teaching and learning materials will be taught in the next semester and the materials are displayed in Table 2.

Table 2. The comparison of prerequisite teaching and learning materials' order between mathematics and physics for senior high schools.

\begin{tabular}{|c|c|c|c|}
\hline Semester & Physics Learning Materials & Prerequisite Materials & Grade/Semester \\
\hline \multirow{11}{*}{$\mathrm{X} / 1$} & \multirow{2}{*}{ Vector } & Basic Trigonometry & $\mathrm{X} / 2$ \\
\hline & & Mathematics Vector & $\mathrm{X} / 2$ \\
\hline & \multirow{5}{*}{ Straight Movement } & Limit & $\mathrm{XI} / 2$ \\
\hline & & Basic Trigonometry & $X / 2$ \\
\hline & & Derivation & $\mathrm{XI} / 2$ \\
\hline & & Integral & $\mathrm{XI} / 2$ \\
\hline & & Mathematics Vector & $X / 2$ \\
\hline & \multirow{4}{*}{ Parabola Movement } & Function & $\mathrm{X} / 2$ \\
\hline & & Basic Trigonometry & $X / 2$ \\
\hline & & Mathematics Vector & $\mathrm{X} / 2$ \\
\hline & & Angle Summation & $\mathrm{XI} / 1$ \\
\hline \multirow{3}{*}{$\mathrm{XI} / 2$} & Momentum and Impulse & Derivation & $\mathrm{XI} / 2$ \\
\hline & \multirow{2}{*}{ Harmonious Vibration } & Derivation & $\mathrm{XI} / 2$ \\
\hline & & Trigonometry Derivation & $\mathrm{XII} / 1$ \\
\hline \multirow{4}{*}{$\mathrm{XI} / 1$} & Balance of Rigid Object & Space Geometry & $\mathrm{XII} / 1$ \\
\hline & Fluid & Space Geometry & $\mathrm{XII} / 1$ \\
\hline & Heat & Space Geometry & $\mathrm{XII} / 1$ \\
\hline & Theory of Gas Kinetic & Space Geometry & $\mathrm{XII} / 1$ \\
\hline
\end{tabular}

The other mathematics teaching and learning materials which have been the prerequisite for the physics teaching and learning process are taught in the same semester with physics. These teaching and learning materials are displayed in Table 3. 
Table 3. The List of mathematics and physics prerequisite teaching and learning materials.

\begin{tabular}{|c|c|c|c|}
\hline Semester & Physics Materials & Prerequisite Materials & Grade/Semester \\
\hline \multirow{7}{*}{$\mathrm{X} / 2$} & Law of Newton (Movement) & Basic Trigonometry & \\
\hline & & Mathematics Vector & $X / 2$ \\
\hline & Power and Energy & Basic Trigonometry & $X / 2$ \\
\hline & & Mathematics Vector & $X / 2$ \\
\hline & Momentum and Impulse & Basic Trigonometry & $X / 2$ \\
\hline & & Mathematics Vector & $X / 2$ \\
\hline & Harmonious Movement & Basic Trigonometry & $X / 2$ \\
\hline
\end{tabular}

The findings on the non-ideal material sequence have been supported by the field data which show that most of the teachers perceive the relative low mathematical function in supporting the physics teaching and learning process. Such problems have not been followed up by systematically, procedural, and concrete steps as part of the problem solution. This assumption is based on the fact that the teachers rarely conduct a review toward the match between the teaching and learning materials in mathematics and in physics within the curriculum and disseminate the results of their review in the school's internal discussion and in the Forum of Subject Teachers. Up to date, the review activities have been the accidental ones when the physics teachers find certain problems and crosscheck these problems to their students through question and answer sessions or through discussions with the mathematics teachers in an informal situation. The findings from such review have not even been followed up systematically, whereas the sequence in the teaching and learning materials between mathematics and physics that has not been synchronized becomes the main cause of the low mathematical supporting ability in the physics teaching and learning process.

The results of data reduction toward the teacher response in dealing with the situations of the students who attend the teaching and learning process without having been equipped with the prerequisite ability can be viewed in Table 4.

Table 4. The teachers'response in dealing with the unsynchronized learning materials between mathematics and physics.

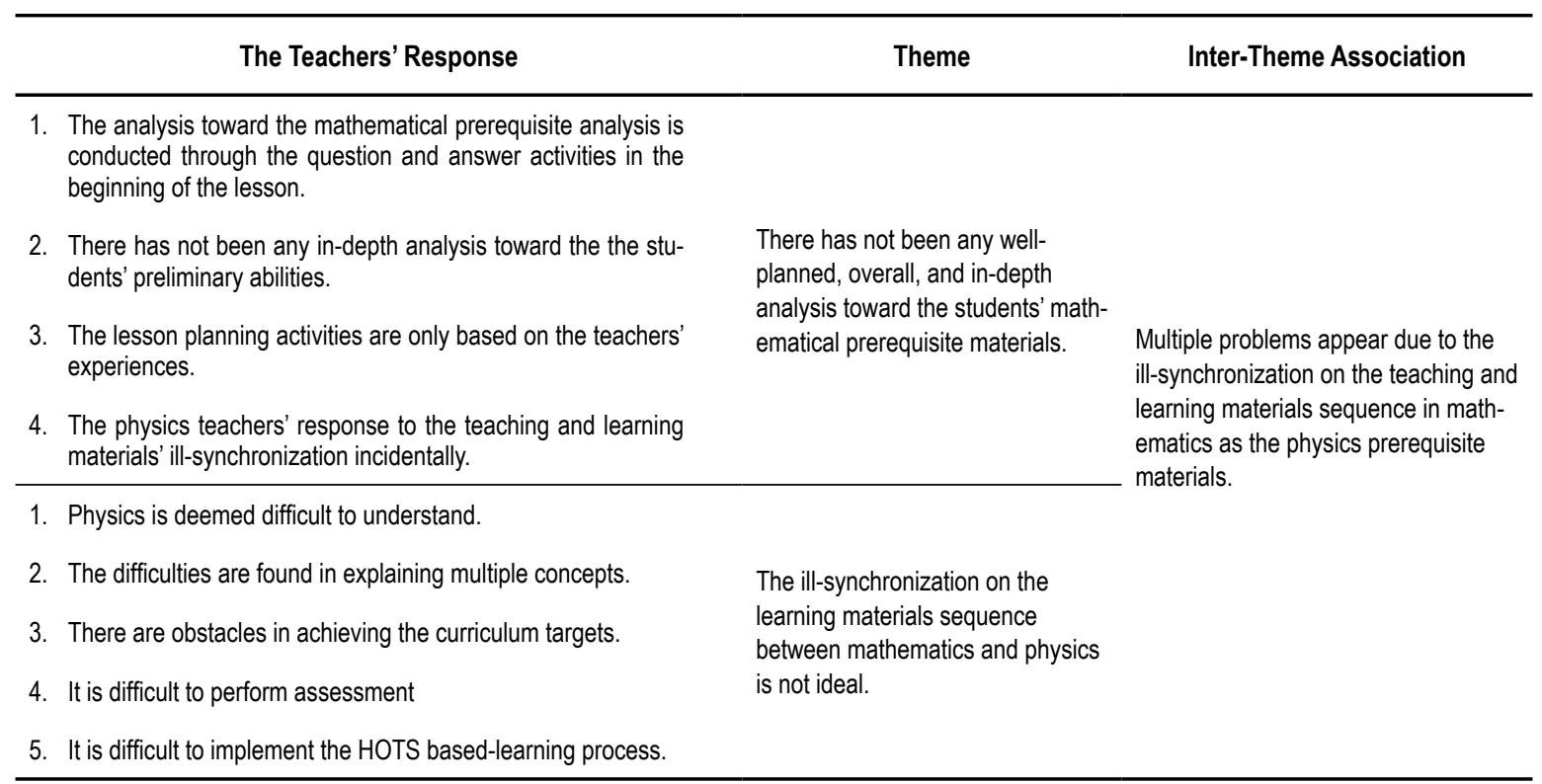


Lesson planning activities are one of the most important processes that determine the fluent teaching and learning activities in the classroom. The students' preliminary ability and prerequisites are very important to be identified because through their preliminary ability and prerequisites the teachers may lay their foundation in developing the teaching and learning scenario. The elaboration of the lesson plan in a special format becomes very important because this lesson plan will be the matter of reference so that the teachers will be more ready and responsive in responding to the problems. However, in the practice most of the teachers do not conduct any structured analysis and planning in dealing with the problems of mismatched teaching and learning materials between mathematics and physics. The weak analysis and planning add the confusion in this non-ideal physics teaching and learning process. The lack of careful analysis toward the sequence of teaching and learning materials between mathematics and physics renders the teachers unable to prepare the best alternative solution and, in the same time, the absence of careful planning renders the teachers unable to perform preventive acts immediately and appropriately.

The impact of mathematical ill-functionality in supporting the physics teaching and learning process is very complex. First, physics has an impression of being a difficult lesson to learn. This has been caused by the fact that the physics teaching and learning process contains two agendas namely explaining the mathematical prerequisites and explaining the physics teaching and learning materials. Thus, the physics teaching and learning process becomes very heavy and complicated.

Second, physics teachers have difficulties in explaining the mathematics prerequisite learning materials. This has been caused by the fact that physics teachers do not have the competencies of mathematics teachers. During the explanation, most of the times physics teachers have difficulties in elaborating mathematics prerequisite materials well. Time limits cause these teachers to be hesitant in explaining the prerequisite materials; as a result, the focus will be in the domain of application, conciseness, and memorization-based. Most of physics teachers ask their students to follow up the introduction to the prerequisite materials to mathematics teachers so that they will gain better understanding.

Third, physics teachers deal with difficulties in achieving the curriculum targets. The minimum initial capital of the prerequisite materials has caused the teaching and learning process to be inhibited. The facts that have been found show that physics teachers should repeat the prerequisite materials over and over in the middle of the teaching and learning process because the students have been inhibited in the mathematical sequence. This situation has caused the teaching and learning process to be stuck; the preliminary materials spend most of the times because physics teachers try to explain the prerequisite materials as good as they can. As a result, it is no wonder that in the last month physics teachers still have plenty teaching and learning materials that should be learned by students and they have to speed themselves up in order to complete the distribution of these teaching and learning materials.

Fourth, the assessment model has not been ideal. Physics teachers should be accustomed to the students' relatively minimum mathematical ability; thus, these teachers devise test items with simple numbers and even with simple thinking process. Even in such conditions, there have been still many students who do not pass the minimum score (most of them have been stumbled in the mathematical sequence instead of the physical one). Due to this situation, the students should take remedies for several times.

Fifth, it had been difficult to meet the curriculum demands that emphasize the higher-order thinking skills (HOTS)-based learning process. Students with quite good mathematical understanding usually have keen logic so that they are able to use any concepts that they have possessed in order to solve problems that demand indepth analysis. These students are also able to operate the data from the observed symptoms into the formula of the materials under study. On the other hand, the students who have low mathematical understanding (whose number is higher) are usually able to memorize formulas only and are unable to interpret the relationship among properties in the formulas; these students are even unable to deal with the HOTS-based learning cases.

\section{Physics Teachers' Strategies}

Behind the problems of low mathematical supporting ability in the physics teaching and learning process due to the ill-synchronized teaching and learning materials arrangement, physics teachers should ensure that the teaching and learning process is accomplished and the curriculum targets might be achieved. The data on the reduction of teachers' initiatives in dealing with the problems of low synergy between the prerequisite teaching and learning materials of mathematics and those of physics are provided in Table 5. 
Table 5. The teacher's initiative to cover the difficulties.

\begin{tabular}{|c|c|c|}
\hline The Teacher's Initiative & Theme & Inter-Theme Association \\
\hline $\begin{array}{l}\text { 6. The discussion between the physics teachers and the math- } \\
\text { ematics teachers is conducted informally. } \\
\text { 7. It is difficult to create collaboration between the physics } \\
\text { teachers and the mathematics teachers. }\end{array}$ & $\begin{array}{l}\text { The curriculum targets cause the collaboration } \\
\text { to be difficult to achieve. }\end{array}$ & \\
\hline $\begin{array}{l}\text { 1. The physics teachers deliver the prerequisite materials at } \\
\text { the beginning the learning process. }\end{array}$ & & $\begin{array}{l}\text { Time limitation, authority, } \\
\text { competence, and curriculum }\end{array}$ \\
\hline $\begin{array}{l}\text { 2. The activities of teaching the prerequisite materials waste } \\
\text { a lot of time. }\end{array}$ & $\begin{array}{l}\text { The physics teachers' individual strategies } \\
\text { are teaching the prerequisite materials in } \\
\text { the beginning of the teaching and learning }\end{array}$ & $\begin{array}{l}\text { the teachers to be difficult to } \\
\text { find initiatives; as a result, } \\
\text { the physics teachers decide }\end{array}$ \\
\hline $\begin{array}{l}\text { 3. The prerequisite materials are integrated into the teaching } \\
\text { and learning process. }\end{array}$ & $\begin{array}{l}\text { process, allocating special time, providing } \\
\text { assignments, and integrating the prerequisite } \\
\text { materials in the middle of the teaching and }\end{array}$ & to take their own actions. \\
\hline $\begin{array}{l}\text { 4. The physics teachers allocate special time outside the teach- } \\
\text { ing and learning process. }\end{array}$ & learning process. & \\
\hline
\end{tabular}

In general, the teachers have an initiative of having discussions with mathematics teachers. However, the discussions are informal. The objective of the discussions is identifying that the mathematics prerequisites have been taught or not; thereby, physics teachers might define which mathematics contents that should be taught. In addition, physics teachers often open the discussions with mathematics teachers in order to ask about the manners of teaching mathematical prerequisites briefly, comprehensively, and accurately in order to support certain teachings of physics materials.

For the further step, namely collaboration, physics teachers have found it difficult. Only few teachers have performed such collaboration, namely by changing the order of the teaching and learning materials according to the agreement; this has been done by Teacher 15. However, the change of the order has been performed on the materials for one semester. In the condition of the latest curriculum sequence, according to the Minister of Education and Culture Number 24 Year 2016 physics teachers are only allowed to change the teaching and learning materials for the grade XI students because the supporting prerequisite materials of both mathematics and physics are contained in Semester 1. For the situation in which the prerequisite materials of mathematics and physics are in the different semester, these teachers may not change the sequence.

The data from other teachers show that such strategy has been impossible to implement in each school because it takes common communication and planning, which has been complex, especially when the parallel classrooms are handled with different physics and mathematics teachers. The adjustment will become more difficult because each subject has different curriculum targets. Thereby, the inter-teacher collaboration is still rare between the physics teachers and the mathematics teachers.

The most general solution will be teaching the prerequisite materials independently. There are two strategies that the teachers select: teaching the prerequisite materials in the beginning of the subject and integrating these materials into the subject. In the first strategy, the teachers allocate around one teaching hour (45 minutes) specifically for explaining the prerequisite materials. These materials are taught briefly and applicably according to the needs of the materials; one of the examples is the materials of vectors and linear movement demands an understanding toward the concept of trigonometry. The teachers will review the techniques of determining the results of sinus, co-sinus, and tangent for special angles; then, they will apply the understanding into the concept of linear movement vector. If it is possible, the teachers will spend another one teaching hour outside the teaching and learning process; on the other hand, if it is fine the teachers will cut their physics teaching hours.

In the second strategy, as having been mentioned in the previous section, the teachers will integrate the teaching and learning materials into physics. The teachers will teach the prerequisite materials when they find that the students have confusion in the mathematical sequence during the teaching and learning process. One 
of the examples can be found in the materials of kinematics with vector analysis. Sometimes, in the test items the students are asked to determine the momentary speed when they know the movement equation. Therefore, the teachers will explain briefly how they should convert the position equation into the speed equation and even the velocity equation; similar manners are also applied when they deal with differentials and integrals.

The amount of physics teaching and learning time that has been wasted due to the strategy of integrating the prerequisite materials are similar to that of the first strategy, namely one teaching and learning period. If the students easily understand the learning materials of differentials and integrals then the teachers will spend only one teaching and learning hour in teaching those materials; however, if the students have difficulties in understanding those teaching and learning materials then the teachers will take a longer time in explaining them. The teachers will select the first or the second strategy based on their habit, their comfort, and their teaching style.

The problems of time allocation in explaining the prerequisite materials become more complicated in the era of Curriculum 2013 because the time allocation for physics is only three teaching and learning periods. This time is considered imbalanced compared to the material contents that should be taught first if physics teachers should explain the mathematical prerequisite materials. The teachers argue that the time allocation in the previous curriculum has relatively been better, namely four teaching and learning periods in each week. With such time allocation, the teachers feel that they have more flexibility in teaching the prerequisite materials both in the beginning of the teaching and learning process and in the integration into the teaching and learning process. This becomes a peculiar difficulty and dilemma for the teachers because it is better for them to use this time allocation for performing remedial repetitively or for continuing the teaching and learning materials explanation rather than teaching the mathematics teaching and learning prerequisites.

In response to the time allocation within the Curriculum 2013, the teaching and learning process which only takes 3 teaching and learning hours per week will result in more narrowed time of prerequisite material distribution. Physics teachers consider that this situation will spend longer time on teaching the mathematical prerequisite materials, which will be a disadvantage for them. Therefore, many physics teachers respond to the situation by compressing the distribution time of prerequisite materials and strengthening the teaching and learning process toward the prerequisite materials by providing tasks in the form of test items and material resumes.

The collaborative efforts can be turned into an alternative for looking for collaborative solutions. The reduction on the data regarding the efforts of physics teacher community in responding to the problems of low support from the mathematical prerequisite materials is elaborated in Table 6.

Table 6. The collaborative efforts of physics teacher community in responding to the problems.

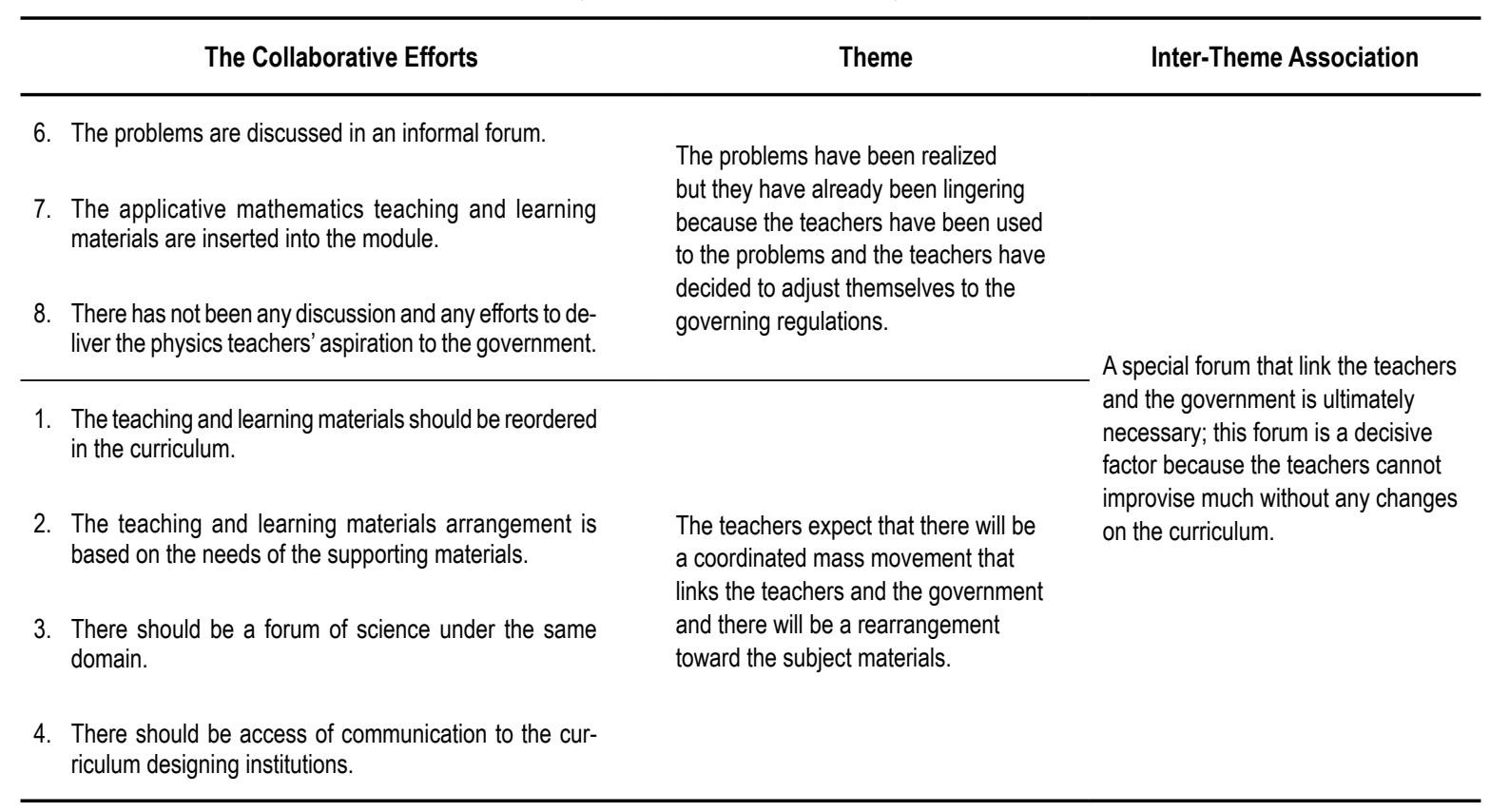


The problems of sequence between mathematics and physics have been perceived by all of the related teachers; unfortunately, these problems have not been discussed in a forum. A specific review in the Forum of Subject Teacher Discussion Group has not been conducted as well. The teachers' focus is on the innovation instead of the ordering on the material sequence. There is a conclusion that the researchers might draw, namely that these teachers have been trying to survive in the system and have been adjusting themselves as they can. Such attitude also appears among the physics teachers; this situation is apparent from the policy in dealing with the problems within the Forum of Subject Teacher Discussion. Although the review regarding the appropriate sequence between mathematics and physics prerequisite materials has never specifically been discussed in the scope of Subject Teacher Discussion; however, such discussion has been conducted informally for several times. Luckily, the Subject Teacher Discussion of Kudus has a common product in the form of physics teaching and learning module so that the Discussion might flexibly input the mathematics prerequisite materials in the beginning of the topic or in addition to explaining the materials that demand the competencies of mastering the prerequisite materials.

The absence of formal discussion that results in an in-depth review has caused the problem to stop on the scope of Subject Teacher Discussion. The physics teachers are pessimistic on their own abilities as a physics teacher in delivering their aspiration to the central government; whereas, all teachers do realize that without the government's intervention, the problems of material sequence order will never be solved. One form of government's intervention to cover the problems is curriculum development.

Various topics through which the physics teachers expect that the physics teaching and learning process will be conducted better in the future are as follows. First, the curriculum should be improved in terms of material sequence and time allocation. Multiple prerequisite materials of mathematics and physics that have not been synchronized should be reordered so that the mathematical supportive ability toward physics will be more optimal. In addition, the 3 teaching and learning period-time allocation per week is deemed very limited or insufficient and is imbalanced compared to the amount of teaching and learning materials that should be taught. These problems become worse when some students have not mastered the prerequisite materials; as a result, the teachers should review these materials which spend some more time. Second, the role of mathematics as a foundation of science should be returned so that the stipulation and the development of the teaching and learning materials may be adjusted to the needs of other teaching and learning materials such as physics, chemistry, biology, and even economics. Third, a forum of discussion for teachers under the same domain should be established. This discussion group might involve the teachers whose subjects are interrelated, such as those from the exact sciences, so that they might support from one to another. Discussion becomes highly important because through the discussion the teachers might discuss the teaching and learning obstacles that occur due to the fact the fundamental lessons have not been taught or due to the fact that the teaching and learning results have not met their functions as the prerequisite teaching and learning materials. Fourth, the government might provide a space of communication in order that the teachers might deliver their aspiration easily. The provision of an online-based space will be helpful since it does not involve red-taped bureaucracy.

\section{Discussion}

Most physics lessons make use of mathematics foundation both in the junior high schools and the higher degrees. However, based on the results of the study, the researchers have found that there have been several problems within the physics teaching and learning process that demands the presence of mathematics prerequisite materials. The first problem, which is the beginning of all problems, is the unsynchronized material sequence in the mathematics and the physics curriculum; this situation has caused the teaching and learning process to be inhibited. As a result, physics deems to be a difficult lesson to study. Such impression is not caused merely by the complexity of the physics content; instead, it has been caused by mathematics prerequisite materials that should be taught in physics (Basson, 2002; Duit, Niedderer \& Schecker, 2007; Linn, Tan, \& Tsai, 2013; Pietrocola, 2008). The first problem triggers the occurrence of the second problem, namely that the physics teachers have more workloads because they have to teach mathematics first in addition to physics. It should be conducted this way because mathematics has several prerequisite materials that are necessary for physics. Therefore, the teaching activities of physics entail two agendas that are explaining the mathematics prerequisite materials and the physics teaching and learning materials. As a result, the physics teaching and learning process becomes heavier and more complicated. This situation then becomes an additional burden for the physics teachers. In the 
same time, this situation is in accordance with the teaching challenges that the physics teachers have to deal with in teaching physics with the mathematical prerequisite materials that have not been taught (Chiu, 2015). Not to mention, based on the data of the study that have been gathered from the field, the physics teachers have difficulties because they have to explain the mathematics teaching and learning materials. The reason is that they do not master the competencies of mathematics teacher.

During the teaching learning process, the physics teachers most of the times have difficulties in explaining the mathematical prerequisite teaching and learning materials well. In relation to the teaching challenges (Chiu 2015), the mathematics teachers are in dilemma when they have to teach again the teaching and learning materials which application and implementation have been studied in physics. The situation becomes more difficult because the physics teachers have to speed up their performance in teaching the mathematical prerequisite materials due to the limited time allocation; as a result, the focus of their teaching activities is in the domain of application, conciseness, and memorization-based method.

The diminished time allocation for the physics teaching and learning process in explaining the mathematical prerequisite materials leads to the subsequent problem. The third problem is that the physics teachers have difficulties in achieving the curriculum targets. As having been argued by Basson (2002), the physics teachers spend most of their time for teaching mathematics in the beginning briefly; they will only teach the mathematics teaching and learning materials that will serve as the physics prerequisite materials.

The chain of problems and difficulties that the physics teachers should deal with does not stop there. Due to the limited time allocation and the physics curriculum loads, the assessment process is not ideal since they have been stumbled on mathematics. The physics should also explain the mathematics teaching and learning materials while they are solving the physics problems if the students have mathematical obstacles; as a consequence, the time allocation becomes less effective and wasted. In addition, if the teachers have to deal with the students who have low mathematics proficiency, then they will design test items with simple routines and numbers and even with simple thinking skills. Ideally, the assessment that the physics teacher should conduct is equipped with the remedial activities for the students who have not met the passing grade and with enrichment materials for the students who have mastered the lessons (Nashon, Anderson \& Nielsen, 2009).

Still another problem that appears from the physics teaching and learning process that has not been preceded by the mathematics teaching and learning process is the difficulties in achieving the curriculum demand that emphasizes on the higher order thinking skill (HOTS) based-learning process. The results of this study are in accordance to the results of a study case by Chiu (2015); in his study, he found that one of the physics teachers' difficulties is that they have not been able to create any teaching and learning process that emphasizes the HOTS. This matter starts from the following question: which aspect should be the priority, the thinking skill or the content that should be improved in the physics teaching and learning process. The physics curriculum demands the physics teachers to teach a number of physics teaching and learning contents which are complex and demanding. Different than mathematics curriculum which aims to improve the thinking skills, the physics curriculum emphasizes more on the improvement of the content under the study as a form of rapid scientific development which does not negate the importance of mathematics as a tool in physics (Chiu, 2015). The students with moderately good mathematics proficiency usually have cunning logics so they can use all concepts in solving problems that demand in-depth analysis. They are different than the students who have poor mathematics proficiency and who can only memorize formulas; the students with poor mathematics proficiency have not been able to change the scales in the formulas. This type of students has not even been able to implement the formulas into the HOTS based-learning cases. These problems that have arisen from the ill-synchronization between mathematics curriculum and physics curriculum render mathematics malfunctioned in supporting the physics teaching and learning process.

The problems that have appeared are not immediately analysed and followed up by the physics teachers; as a result, these problems cannot be minimized. Not to mention, as educators these teachers should conduct the government's policies in relation to education and should follow the national curriculum that has been governed, although they have disagreement toward the policy of the content sequence and the curriculum that has been approved (Hart, 2001). Therefore, certain strategies should be taken by the physics teachers both individually and collaboratively. In general, the physics teachers initiate discussions with the mathematics teachers. However, a further step, namely collaboration, is difficult to perform. Most of the mathematics teachers perceive that they do not have to collaborate with the physics teachers (Tursucu, 2017). In addition, the mathematics teachers also question whether it is possible or not to change the mathematics teaching and learning sequence earlier for 
accommodating certain concepts that will be used in physics. Unfortunately, the mathematics sequence cannot be changed because the mathematics teachers have their own curriculum sequence that should be followed. Such phenomenon does not only occur in Indonesia but also in Taiwan (Chiu, 2015). In order to accomplish this, teachers can arrange a sequence of teaching and learning materials in a learning trajectory (Retnawati, 2017), or teachers in collaboration with the policy makers revise the current curriculum.

There are only few teachers who have performed a breakthrough by changing the materials sequence according to their agreement. This solution used to be performed by the physics teachers in Taiwan in order to accommodate the physics teaching and learning process that demands the mathematics prerequisites (Chiu, 2015). The physics teachers in Taiwan might change the content sequence that had already been stipulated by the national curriculum in relation to the materials that will be taught to the students. However, it does not mean that this solution does not bear any risk. The change on the curriculum sequence that a school performs obviously impacts the textbook that will be referred to. This textbook should be adjusted to the nationally governed curriculum. Chiu (2015) also asserted in his case study that physics teachers have been allowed to teach several concepts of mathematics, but this is not a necessity. If they feel that they have not been able to teach mathematics, then they may have collaboration with mathematics experts or teachers through the use of modern technology (Chiu, 2015).

Then, the most general solution from the teachers is teaching the prerequisite materials independently. There are two strategies that the teachers select: teaching the prerequisite materials in the beginning of the learning process or integrating the prerequisite materials in the middle of the physics teaching and learning process. The research result in line with Nashon, Anderson, \& Nielsen (2009), that the importance of students' preliminary understanding toward mathematics is the physics teaching and learning process. The teachers teach the prerequisite materials when the students do not understand the mathematical sequence in the middle of the teaching and learning process (Uhden, Karam, Pietrocola, \& Pospiech, 2011). Pietrocola (2008) also asserted that since mathematics becomes an important part of physics learning process one of the learning models that might be implemented into physics is teaching mathematics by means of physics contents and structures.

On the other hand, in response to the time allocation in Curriculum 2013, physics which has been allocated with 3 teaching and learning periods per week certainly has limited time in delivering the prerequisite materials. Therefore, many physics teachers cut off the time allocation for the prerequisite materials delivery and they will strengthen the students' mastery toward these prerequisite materials by providing assignments in the form of tasks and material resumes. If it is possible then teachers will take one teaching and learning period out of the physics teaching and learning period in order to strengthen the students' mastery toward the prerequisite materials. Several physics teachers in public schools also teach mathematics materials that have been necessary as the physics prerequisite materials; as a result, these teachers have limited time in teaching physics (Chiu, 2015).

Chiu (2015) also displayed in the results of his study, the students should attend a course outside the teaching and learning period if they do not have sufficient mathematics prerequisite for studying physics in order to strengthen the concepts of mathematics that are necessary in physics. This is due to the fact, that the teaching and learning activities within the teaching and learning periods are maximized toward teaching the physics contents. Based on the results of a case study toward the physics teachers in Taiwan, it is found that teaching mathematics is not an obligation for the physics teachers because they are advancement that has been taking place continuously. On the other hand, according to the mathematics teachers' opinion and point of view, the mathematics teachers should teach about how to think mathematically; as a result, it is difficult to teach various contents before the students learn about physics (Chiu, 2015). The mathematics teachers instead view that it should be the physics teachers who change the teaching and learning materials sequence of physics first and the materials that should be changed are the ones that are separate from the concepts of mathematics (Uhden, Karam, Pietrocola, \& Pospiech, 2011; Chiu, 2015). So, the physics teaching and learning process starts from understanding the qualitative concepts first and then it proceeds to the quantitative concepts in mathematics gradually. It should be conducted this way because the mathematics curriculum aims to improve the thinking skills rather than the content; on the other hand, the physics curriculum aims to improve the contents that have been studied in as a form of rapid scientific development that does not negate the importance of mathematics as a tool in physics (Murdock, 2008; Schwartz et al., 2009; Chiu, 2015). In addition, the mathematics curriculum emphasizes more on the improvement of in-depth content rather than the content flexibility. This is intended to support the students' mathematical thinking skills. 
The strategies that have been mentioned above with regards to teaching the prerequisite materials in the beginning of the teaching and learning process, allocating special time, providing assignments, and integrating the prerequisite materials in the middle of the teaching and learning process are the individual strategies. As an alternative, with regards to the communal or the collaborative strategies or solutions the Subject Teachers Discussion on Physics insert the prerequisite materials into the module that has been collaborative produced by the members. The design of this special module or book can be an alternative solution for the physics teaching and learning process that demands the use of mathematics prerequisite materials by means of mathematical contents insertion and integration into the physics teaching and learning process (Boas, 2006; Nearing, 2010; Tursucu, 2017). However, these various solutions will result in small impact and the problems will still linger as long as the government does not take any action to change the curriculum. The cooperation in identifying and improving multiple aspects for designing a coherent mathematics curriculum will help decrease the frustration and the depression of the physics teachers who have taken extra time to teach the mathematics again in the classroom (Hatch \& Smith, 2004; Tursucu et al., 2017).

The absence of formal discussion that results in an in-depth review has made the discussion of this problem to stop in the scope of Subject Teachers Discussion. This finding is in accordance to the results of a study case by Chiu (2015); in his case study, he explained that the forum that the school teachers establish for channelling their complaints is meaningless. This is the reason why the physics teachers are more inclined to teach the mathematics prerequisite materials. Chiu (2015) explained that the role of the principal is very important changing the sequence of the cross-sectional curriculum content. Still based on the same case study, Chiu (2015) explained that the principals of the schools that have been located in the village areas tend to have easier communication in changing the sequence of the teaching schedule for certain contents. On the other hand, the principals of the schools that have been located in the city areas are more pessimistic in terms of formally changing the teaching and learning contents sequence. He also explained that for the schools in the city areas the only way the physics teachers deliver the mathematics prerequisite materials is adjusting the materials to their own professionalism or abilities. Return to the case, the appearance of various difficulties has been caused by the ill-synchronization between the mathematics curriculum and the physics curriculum and these problems demand a solution from the government in order that the inter-disciplinary curriculum will be more arranged and coherent.

\section{Conclusions}

There have been problems of ill-synchronization between the mathematics teaching and learning materials sequence and the physics teaching and learning materials sequence; these problems obscure the physics teaching and learning process and, as a result, the physics teaching and learning process are deemed difficult. The physics teachers have difficulties because they have to explain the mathematics materials, they have difficulties in achieving the curriculum targets, and they have difficulties in performing ideal HOTS based-assessment. The weak analytical efforts and plan by the teachers have also caused these problems to not be minimized.

The individual strategies that the physics teachers implement are teaching the prerequisite materials in the beginning of the teaching and learning process, allocating special time, providing assignments, and integrating the prerequisite materials into the teaching and learning process. On the other hand, the communal strategy is that the Subject Teachers Discussion on physics inserts the prerequisite materials into their module that has been produced collaboratively by the members. However, these solutions only result in small impact and the problems will still linger as long as the government does not take any action to change the curriculum.

\section{References}

American Association of Physics Teachers. (2015). Physics and the next generation science standards. Retrieved from https://www. aapt.org/K12/upload/Physics-in-the-NGSS.pdf.

Aziz, N. D. (1988). Integration of mathematics and physics in secondary schools: An integrated mechanics unit for Egypt. International Journal of Mathematical Education in Science and Technology, 19 (6), 819-821.

Basson, I. (2002). Physics and mathematics as interrelated fields of thought development using acceleration as an example. International Journal of Mathematical Education in Science and Technology, 35(5), 679-690, https://doi. org/10.1080/00207390210146023.

Boas, M. L. (2006). Mathematical methods in the physical sciences, 3rd ed. Hoboken, NJ: John Wiley \& Sons, Inc.

Bogdan, R. C., \& Biklen, S. K. (1982). Qualitative research for education: An introduction to theory and methods. Boston, MA: Allyn and Bacon. 
Chiu, M. (2015). The challenge of learning physics before mathematics: a case study of curriculum change in Taiwan. Research in Science Education, 46 (6), 767-786. Doi: https://doi.org/10.1007/s11165-015-9479-5.

Creswell, J. W., \& Clark, V. L. (n.d.). Principles of qualitative research: Designing a qualitative study. Retrieved from http://www. andrews.edu/leaderpart/RoundTable/.

Doran, Y. J. (2017). The role of mathematics in physics: Building knowledge and describing the empirical world. Onomázein, Número especial, 209-226. DOI:10.7764/onomazein.sfl.08.

Duit, R., Niedderer, H., \& Schecker, H. (2007). Teaching physics. In S. K. Abell \& N. G. Lederman (Eds.), Handbook of Research on Science Education (pp. 599-629). Mahwah, MA: Lawrence Erlbaum Associates.

Fiss, A. (2012). Problems of abstraction: Defining an American standard for mathematics education at the turn of the twentieth century. Science \& Education, 21 (8), 1185-1197. Doi: https://doi.org/10.1007/s11191-011-9413-9.

Gingras, Y. (2001). What did mathematics do to physics? History of Science, xxxix, 383-416. Retrieved from http://www.archipel. uqam.ca/443/1/gingras-mathematics.pdf.

Hart, C. (2001). Examining relations of power in a process of curriculum change: The case of VCE physics. Research in Science Education, 31 (4), 525-551. Doi: https://doi.org/10.1023/A:1013145924470.

Hatch, G. M., \& Smith, D. R. (2004). Integrating physical education, math, and physics. Journal of Physical Education, Recreation \& Dance, 75 (1), 42-50. Doi: http://dx.doi.org/10.1080/07303084.2004.10608541.

Hudson, H. T., \& McIntire, W. R. (1977). Correlation between mathematical skills and success in physics. American Journal of Phys$i c s, 45$ (5), 470-471. Retrieved from http://people.physics.tamu.edu/toback/TeachingArticle/Hudson_McIntyre_AJP.pdf.

Lawrenz, F., Wood, N. B., Kirchhoff, A., Kim, N. K., \& Eisenkraft, A. (2009). Variables affecting physics achievement. Journal of Research in Science Teaching, 46 (9), 961-976. Doi: https://doi.org/10.1002/tea.20292.

Lin, T.-J., Tan, A. L., \& Tsai, C.-C. (2013). A cross-cultural comparison of Singaporean and Taiwanese eighth graders' science learning self-efficacy from a multi-dimensional perspective. International Journal of Science Education, 35, 1083-1109. Retrieved from https://eric.ed.gov/?id=EJ1011935.

Murdock, J. (2008). Comparison of curricular breadth, depth, and recurrence and physics achievement of TIMSS population 3 countries. International Journal of Science Education, 30, 1135-1157.

Nashon, S. M., Anderson, D. \& Nielsen, W. S. (2009). An instructional challenge through problem solving for physics teacher candidates. Asia-Pacific Forum on Science Learning and Teaching, 10 (1), 1-21. Retrieved from http://ro.uow.edu.au/cgi/ viewcontent.cgi?article $=1103 \&$ context=edupapers.

National Research Council. (1996). National science education standards. Washington, DC: National Academy Press. Retrieved from http://www.nap.edu/catalog/4962.html

National Research Council. (2013). The mathematical sciences in 2025. Washington, DC:The National Academies Press. Doi: https:// doi.org/10.17226/15269.

Nearing, J. (2010). Mathematics tools for physics. Miami, FL: University of Miami.

Nilse, T., Angell, C., \& Gronmo, L. S. (2013). Mathematical competencies and the role of mathematics in physics education: A trend analysis of TIMSS Advanced 1995 and 2008. Acta Didactia Norge, 7 (6), 1 - 21. Retrieved from https://www.journals.uio.no/ index.php/adno/article/viewFile/1113/992.

Pospiech, G., Karam, R., Bagno, E., Redish, E.F., Bohm, U., Pietrocola, M., ..., Bing., T.. (2009). Mathematization in physics lessons: problems and perspectives. Physics Community and Cooperation, 2, 66 - 70, GIREP-EPEC \& PHEC 2009 International Conference, August 17-21, University of Leicester, UK.

Pietrocola, M. (2008). Mathematics as structural language of physical thought. In M. Vicentini \& E. Sassi (Eds.) Connecting Research in Physics Education with Teacher Education, 2. International Commision on Physics Education. Retrieved from http://www. iupap-icpe.org/publications/teach1/ConnectingResInPhysEducWithTeacherEduc_Vol_1.pdf.

Quale, A. (2011). On the role of mathematics in physics. Science \& Education, 20, 359-372.

Redish, E. F. (2005). Problem solving and the use of math in physics course. Paper presented in conference World View on Physics Education in 2005, Delhi, August 21-26, 2005. Retrieved from http://www.physics.umd.edu/perg/papers/redish/IndiaMath.pdf.

Redish, E. F. \& Bing, T. J. (2009). Using math in physics: warrants and epistemological frames. Physics Community and Cooperation, 2, GIREP-EPEC \& PHEC 2009 International Conference, August 17-21, University of Leicester, UK, 71-76.

Retnawati, H., Hadi, S., \& Nugraha, A. C. (2016). Vocational high school teachers' difficulties in implementing the assessment in curriculum 2013 in Yogyakarta Province of Indonesia. International Journal of Instruction, 9(1), 33-48. Retrieved from http:// www.e-iji.net/dosyalar/iji_2016_1_3.pdf.

Retnawati, H., Kartowagiran, B., Arlinwibowo, J., \& Sulistyaningsih, E. (2017). Why are the mathematics national examination items difficult and what is teachers' strategy to overcome it? International Journal of Instruction, 10 (3), 257-276. Doi: https://doi. org/10.12973/iji.2017.10317a.

Retnawati, H. (2017). Learning trajectory of item response theory course using multiple software. Olympiads in Informatics, 11, 123-142. Doi: https://doi.org/10.15388/ioi.2017.10.

Retnawati, H., Munadi, S., Arlinwibowo, J., Wulandari, N. F., Sulistyaningsih, E. (2017). Teachers' difficulties in implementing thematic teaching and learning in elementary schools. The New Educational Review, 48(2), 201-212. Doi: https://doi.org/10.15804/ tner.2017.48.2.16.

Sari, R., \&Wijaya, A. (2017). Mathematical literacy of senior high school students in Yogyakarta. Jurnal Riset Pendidikan Matematika, 4 (1), 100-107. doi:http://dx.doi.org/10.21831/jrpm.v4i1.10649.

Schwartz, M. S., Sadler, P. M., Sonnert, G., \& Tai, R. H. (2009). Depth versus breadth: How content coverage in high school science courses relates to later success in college science coursework. Science Education, 93, 798-826. 
ISSN 1648-3898 /Print/ TEACHERS' DIFFICULTIES AND STRATEGIES IN PHYSICS TEACHING AND LEARNING THAT

Simons, P. (2001). Review the applicability of mathematics as a philosophical problem. British Society for the Philosophy of Science, 52, 181-184.

Steiner, M. (1998). The applicability of mathematics as a philosophical problem. Cambridge, MA: Harvard University Press.

Tasar, M. F. (2010). What part of the concept of acceleration is difficult to understand: the mathematics, the physics, or both? ZDM Mathematics Education, 42, 469-482. Doi: https://doi.org/10.1007/s11858-010-0262-9.

Tursucu, S., Spandaw, J., Flipse, S., \& de Vries, M. J. (2017). Teachers' beliefs about improving transfer of algebraic skills from mathematics into physics in senior pre-university education. International Journal of Science Education, 39 (5), 587-604. Doi: http://dx.doi.org/10.1080/09500693.2017.1296981.

Uhden, O., Karam, R., Pietrocola, M., \& Pospiech, G. (2011). Modelling Mathematical Reasoning in Physics Education. Science \& Education, 21 (4), 485-506. Doi: https://doi.org/10.1007/s11191-011-9396-6.

Wigner, E. P. (1960). The unreasonable effectiveness of mathematics in the natural sciences. Communications on Pure and Applied Mathematics, xiii, $001-14$

Tzanakis, C. (n.d.). On the relation between mathematics and physics in undergraduate teaching. Retrieved from http://users.math. uoc.gr/ ictm2/Proceedings/pap319.pdf.

Heri Retnawati

Janu Arlinwibowo

Nidya F. Wulandari

Rian G. Pradani
Dr, Associate Professor, Mathematics Department, Mathematics and Science Faculty, Yogyakarta State University, Indonesia, Jl. Kolombo Karangmalang Yogyakarta 55281 Indonesia. E-mail: heri_retnawati@uny.ac.id

M.Pd., Lecturer and Researcher, Muhammadiyah Health Sciences School of Kudus, Indonesia., Jl. Ganesha I, Purwosari, Kudus, Central Java 59316, Indonesia.

E-mail: januarlinwibowo@ windowslive.com

M.Pd., Alumnae, Master Program in Mathematics Education, Graduate School of Yogyakarta State University, Jl. Kolombo Karangmalang, Yogyakarta 55281, Indonesia. E-mail: nidyaferry@gmail.com

SMAN 1 Gebog Kudus, Central Java, Indonesia. E-mail: riangalih.prandani@gmail.com 